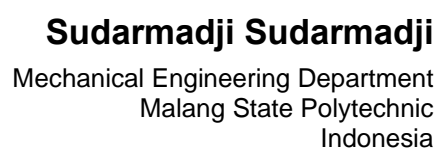

\title{
A New Correlation for Pressure Drop in The Cooling Process of $\mathrm{AL}_{2} \mathrm{O}_{3}$-Water Nanofluid in Pipes
}

This paper discusses the pressure drop of $\mathrm{Al}_{2} \mathrm{O}_{3}$-water nanofluid in laminar flow regimes in circular pipes at different temperatures and $\mathrm{Al}_{2} \mathrm{O}_{3}$ volume concentrations in both cooling and heating processes. The traditional correlation for calculating pressure drop fails to accurately estimate the pressure drop for laminar flows in cooling processes, but for heating processes there is good agreement with the traditional correlation. Accordingly, this study developed new empirical correlations for calculating friction factors in laminar flows in cooling processes at higher volume concentrations ( $0.5 \%)$. This study found that $\mathrm{Al}_{2} \mathrm{O}_{3}$-water nanofluid enhances pressure drop and that temperature rise also reduces pressure drop. The maximum deviations between calculated new correlation and experimental results were reduced to within the $-13.64 \%$ to $+9.98 \%$.

Keywords: Pressure drop, friction factor, $\mathrm{Al}_{2} \mathrm{O}_{3}$-water nanofluid, cooling and heating, laminar flow..

\section{INTRODUCTION}

Heat transfer plays a vital role in many fields such as power generation, air conditioning, transportation and microelectronics, etc. and thus the importance of increasing the efficiency of heat transfer devices used in these fields, and of reducing their size, increasing capacity and decreasing operating costs.

There are several ways to enhance convective heat transfer efficiency such as increasing heat transfer area, altering boundary conditions, changing flow regimes and using rough inner pipe surfaces. Traditional cooling fluids such as water, oil and ethylene glycol have poor heat transfer characteristics which prevent improvement in energy efficiencies and one way to improve the heat transfer rate is to increase the thermal conductivity of the fluid.

More than a century ago Maxwell [1], a scientist and engineer, made great efforts by suspending microsized particles in cooling fluids. However, this suffered from numerous drawbacks, such as erosion of the components through abrasion, clogging, settling of particles and increased pressure drop.

Recent, improvements in nanotechnology have made it possible to produce solid particles with diameters of less than $100 \mathrm{~nm}$ to improve heat transfer efficiency of cooling- fluids, these are called nanofluids [2], and have overcome the above problems.

Many researchers have studied the effects of nanoparticles in cooling fluids and have found they enhance their thermal conductivity characteristics [3][5]. Moreover, various mechanisms and models have been proposed for explaining the enhanced thermal conductivity of nanofluids using various assumptions,

Received: August 2014, Accepted: December 2014 Correspondence to: Sudarmadji Sudarmadji Malang State Polytechnic , Jl. Soekarno-Hatta No.9 PO Box 04 Malang 65141, Jawa-Timur, Indonesia E-mail: sudmaji@yahoo.co.id

doi:10.5937/fmet1501040S

(C) Faculty of Mechanical Engineering, Belgrade. All rights reserved and some have proposed that the enhancement is due to the ordered layering of liquid molecules near the solid particles [6]-[8].

Koo and Kleinstreuer [9], considered the kinetic energy of the nanoparticles to be due to the Brownian motion and proposed a model for the effective conductivity of nanofluids. Reference [10], introduced a Brownion motion based on a convective-conductive model which predicted the right trend with respect to different parameters such as nanoparticles concentrations, diameters and temperature. References [11] and [12] proposed and modeled the Brownion motion induced nanoconvection as a key nanoscale mechanism governing the thermal behavior of nanofluids. In these models, the effects of various parameters such as the ratio of nanoparticle thermal conductivity to the base fluids, volume concentrations, nanoparticle sizes and temperature were examined.

The number studies available on convective heat transfer areas are limited compared to these covering the field of nanofluids in thermal conductivity. Reference [13], reported heat transfer enhancement due to the adition $\mathrm{Al}_{2} \mathrm{O}_{3}$ nanoparticles to deionized water flowing through a copper tube in a laminar flow regime, Their results indicated the nusselt number increased up to $47 \%$ in $1.6 \%$ volume concentrations of nanoparticles.

Experimental investigations into laminar flow forced convection heat transfer of $\mathrm{Al}_{2} \mathrm{O}_{3}$-water nanofluid inside a circular tube with constant wall temperature in heating processes found that the addition of nanoparticles in $2.5 \%$ volume concentrations could enhance average wall heat transfer coefficient by up to $40 \%$ [14].

Yang et al [15] investigated the convective heat transfer coefficient of graphite nanoparticle dispersion in a fluid for laminar flow in a horizontal tube heat exchanger. The results indicated that the heat transfer coefficient increased at higher Reynold numbers and particle volume concentrations 
Duangthongsuk and Wongwises [16], studied forced convective heat transfer and flow characteristics of a nanofluid consisting of water and $0.2 \mathrm{vol} \% \mathrm{TiO}_{2}$ nanoparticles. The results showed that use of a nanofluid had hardly any penalty in pressure drop.

Vajjha et al [17], experimentally investigation of turbulent flow regime convective heat transfer and pressure drop using Alumina oxide, Titanium dioxide and Silicon dioxide nanoparticles, dispersed in $60 \%$ ethylene glycol and $40 \%$ water, at constant wall temperature boundary conditions on a copper tube of a $4.76 \mathrm{~mm}$ diameter and $1.168 \mathrm{~m}$ long. The results indicated that pressure drop increased 4.7 times than that of base fluids at Reynold number 6700 for $10 \%$ particle volume concentrations with alumina nanoparticles and heat transfer increase by $81.74 \%$ for Reynold number 7240 for the same volume concentrations particles.

Suresh et al [18], experimentally studied fully developed laminar convective heat transfer and pressure drop characteristics through a uniformly heated circular tube using $\mathrm{Al}_{2} \mathrm{O}_{3}-\mathrm{Cu} /$ water nanofluids. Their results showed that the maximum enhancement of the Nusselt number was $13.56 \%$ at a Reynolds number of 1730 when compared to the Nusselt number of water [18].

Heyhat et al [19] in a study on convective heat transfer and pressure drop of nanofluids under the constant wall temperature in fully developed laminar regimes, found that the heat transfer coefficient of $\mathrm{Al}_{2} \mathrm{O}_{3}$-water nanofluid increased by $32 \%$ at 2 vol $\%$ compared to that of pure water and that the enhancement of the heat transfer coefficient was larger than that of the effective thermal conductivity at the same volume concentrations. The maximum pressure drop was about 5.7 times higher than that of pure water which occurred at the highest volume fraction of nanofluid (2\%) at Reynolds number of 360 .

Teng et al [20] studied pressure drop of $\mathrm{TiO}_{2} /$ water nanofluid for both laminar and turbulent flow regimes in plain tube for different temperatures. Their results showed that the $\mathrm{TiO}_{2} /$ water nanofluid causes enhancement, but that temperature rise reduced pressure drop. The increase in pressure drop for turbulent flow is lower than that for laminar flow.

Since there has been little research into the pressure drop of nanofluids under cooling processes, especially in fully developed regions, the aim of this research was to investigate the effects cooling processes on pressure drop in $\mathrm{Al}_{2} \mathrm{O}_{3}$-water nanofluids in double pipe heat exchangers in laminar flow regimes. The physical properties and pressure drop of the $\mathrm{Al}_{2} \mathrm{O}_{3}$-water nanofluids were measured.

\section{EXPERIMENT METHOD}

\subsection{The preparation of the $\mathrm{Al}_{2} \mathrm{O}_{3}$-water.}

In this study, 20-50 nm $\gamma \mathrm{Al}_{2} \mathrm{O}_{3}$ of special nanoparticle diameter purchased from Zhejiang Ultrafine powder\&Chemical Co, Ltd China were used. The nanofluid was prepared by dispersing $\mathrm{Al}_{2} \mathrm{O}_{3}$ nanoparticles in different volume concentrations $(0.15$, 0.25 and $0.5 \%$ ) in deionized water as the base fluid. To obtain well dispersed nanofluids, the $\mathrm{pH}$ value of pure water was adjusted by using hydrochloric acid $(\mathrm{HCl})$ and sodium hydroxide $(\mathrm{NaOH})$ thus reducing the influence of the iso-electric point of the alumina $\mathrm{pH}$ level of 9 of the IEP [21].

In order to prevent possible sedimentation in each test, a new nanofluid was prepared and used immediately. Although, no sedimentation was observed after several days of nanofluid preparation, in order to test the stability, some samples of the nanofluids were taken and their density measured before and after each test, no significant changes in density were observed.

\subsection{Viscosity and density measurements.}

A capillary viscometer was used for the tests in the experiment apparatus shown in Fig.1. The capillary viscometer was submerged in a glass tank of water. Water from a constant-temperature bath was pumped into the bottom of the tank and returned to the thermo static bath through an overflow pipe. The water tank was maintained at constant temperature by the water circulation. The dynamic viscosity was determined from the experimental data using the following equation:

$$
\mu=\rho \mathrm{C} t
$$

Where, $\rho$ is the nanofluid density at the same temperature, $\mathrm{C}$ the viscometer constantly obtained calibrated to water at the same temperature and $t$ the time needed for the suspension to fall from position $a$ to $b$.

Nanofluid density was measured by a Picnometer.

\subsection{Pressure drop measurement and friction factor calculation.}

The calculation for the friction factor was done by measuring pressure drop, nanofluid density, flow rate and pipe size using Equation (3) on laminar flow for circular tube, as follows:

$$
\Delta P=f \frac{\mathrm{L}}{\mathrm{d}} \frac{U^{2}}{2} \rho
$$

With the following friction factor for laminar flow:

$$
\begin{gathered}
f=\frac{64}{\operatorname{Re}} \\
\operatorname{Re}=\frac{U \mathrm{~d} \rho}{\mu}
\end{gathered}
$$

Where, $f$ is the friction factor, $d$ is the inner diameter of the pipe, $L$ is the length of pipe, $U$ is the fluid velocity, $\rho$ is the fluid density and $\mu$ is the fluid viscosity. Re represents the low conditions for laminar flow $\mathrm{Re}<$ 2300.

\section{EXPERIMENT DATA ANALYSIS}

\subsection{Experiment apparatus.}

The experimental system used for this study is shown schematically in Fig.1 and comprised of two flow 
circuits, a cooling and heating systems, consisting of a flow loop, a heating unit, a cooling unit, temperature and a pressure drop measuring units. The flow loop contained a reservoir, pump and a valve for controlling the flow rate. To avoid entrance effect, a calming section of straight copper tube $60 \mathrm{~cm}$ long was used in this study. The ratio of length to diameter was greater than $100(\mathrm{~L} / \mathrm{d}>>100)$.

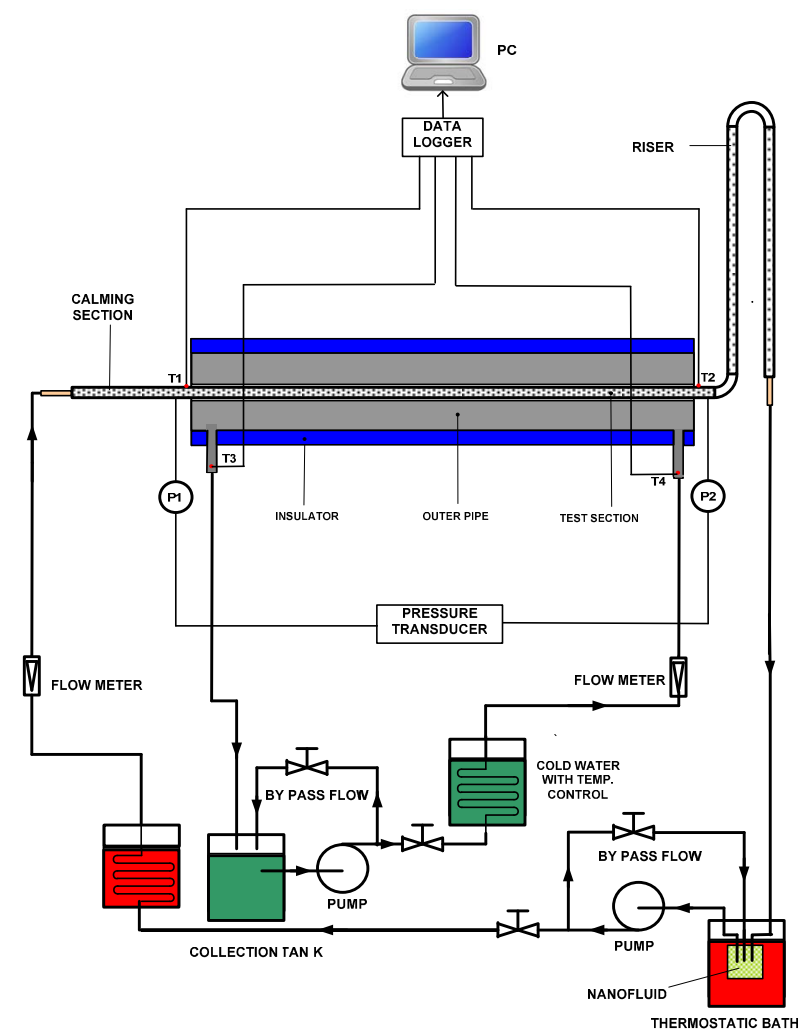

Figure 1. The experimental scheme for pressure drop in the cooling process.

The experiments were done using a counter flow regime in a horizontal double pipe heat exchanger, the inner tube was made from a smooth brass tube $1.25 \mathrm{~m}$ long with a $4.6 \mathrm{~mm}$ inner diameter and a $6.3 \mathrm{~mm}$ outer diameter.The outer tube was a stainless steel tube with a $38.5 \mathrm{~mm}$ outer diameter of $3 \mathrm{~mm}$ thickness. The stainless steel outer tube was thermally isolated using an Aeroflex tube of $38 \mathrm{~mm}$ diameter and $10 \mathrm{~mm}$ thickness. The temperature of the nanofluid at the inlet was maintained at $40^{\circ} \mathrm{C}$ for cooling and $23^{\circ} \mathrm{C}$ for heating (Table 1). Two K-type thermocouples were inserted into the flow at the entrance and exit of the test section to measure the bulk temperatures of the nanofluids and two K-type thermocouples measured the flow at the entrance and exit of the cold water flows in the annular temperatures. During all experiments, all temperatures were recorded by thermocouple data acquisition module, TC-08 PICO TECHNOLOGY UK.

A differential pressure transducer from Brand Omega PX 409-005DWU5V was used for measuring the pressure drop along the test section. The electric heater with a PID controller was installed to keep the temperature of the nanofluid constant.

The cooling tank with a thermostat was used to keep the nanofluid temperature constant. The nanofluid flow rate and cold water were controlled by adjusting the bypass flow valve, and measured by DAKOTA
ACRYLIC rotameter type 6B4100-01B. The fluid passed through the outlet side of the riser section 100 $\mathrm{cm}$ high to keep the inside of inner copper tube continuously full of nanofluid.

Table. 1 Experimental conditions

\begin{tabular}{|c|c|c|c|c|}
\hline Conditions & $\operatorname{Re}$ & $\begin{array}{c}\mathrm{T}_{\text {nanofluid }} \\
\left({ }^{\circ} \mathrm{C}\right)\end{array}$ & $\mathrm{T}_{\text {water }}\left({ }^{\circ} \mathrm{C}\right)$ & $\begin{array}{c}\dot{\mathrm{m}}_{\text {water }} \\
(\mathrm{LPM})\end{array}$ \\
\hline Cooling & $500-2500$ & 40 & 23 & 6 \\
\hline Heating & $500-2500$ & 23 & 40 & 6 \\
\hline
\end{tabular}

\subsection{Uncertainty analysis.}

Uncertainty of experimental results was determined by measuring any deviation in the parameters including density, viscosity, flow rate, weight and temperature. In the pressure drop experiment, nanofluid density $(\rho)$ was measured by a picnometer, viscosity $(\mu)$ by a Ostwald viscometer, flow rate $(V)$ by a rotameter $(6 \mathrm{~B} 4100-01 \mathrm{~B}$, DAKOTA), pressure drop $(P)$ was measured by a differensial pressure transducer (PX409-005DWU5VOMEGA) and the weight $(W)$ of nanoparticles was measured by a precision digital electronic balance (EUROPE 3000-GIBERTINI). The uncertainty of experimental results could be expressed as follows [23]:

$$
u_{m}= \pm\left[\left(\frac{\Delta \rho}{\rho}\right)^{2}+\left(\frac{\Delta \mu}{\mu}\right)^{2}+\left(\frac{\Delta V}{V}\right)^{2}+\left(\frac{\Delta P}{P}\right)^{2}+\left(\frac{\Delta W}{W}\right)^{2}\right]^{\frac{1}{2}}
$$

The uncertainty of the picnometer was $\pm 0.01 \mathrm{~g}$, that of the viscometer $\pm 1.0 \%$, that of the flow meter $\pm 2 \%$, that of the pressure transducer $\pm 2.0 \%$, and that of the precise digital electronic balance was $\pm 0.1 \mathrm{~g}$, and that of the thermocouple $\pm 0.5^{\circ} \mathrm{C}$. Therefore, the uncertainty of this experiment was less than $\pm 6.0 \%$.

\section{RESULTS AND DISCUSSION}

\subsection{Validation of the experimental system.}

The accuracy of fluid flow in the experiment, the predicted pressure drop for the laminar flow was compared to the Heggen-Poiseuille correlation as follows:

$$
\Delta P=\frac{32 \mu L U}{d^{2}}
$$

As shown in Fig. 2, the pressure drop of the hot water inside the tube was a function of the Reynold number at $40^{\circ} \mathrm{C}$ temperature. It can be seen, good agreement exists between experimental data and the theoretical model for laminar flow.

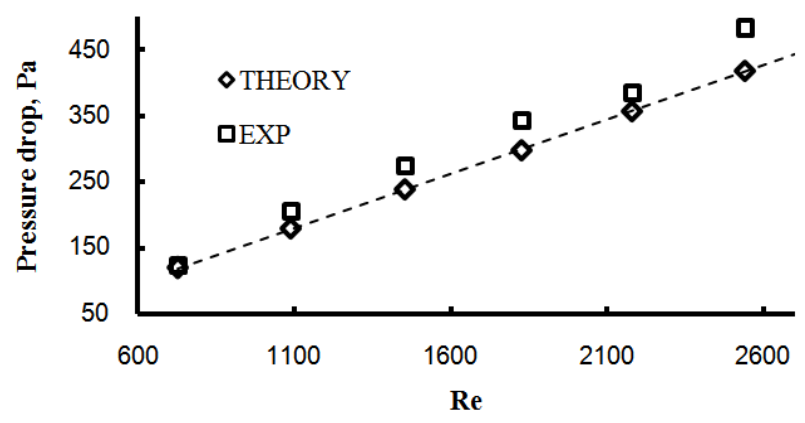

Figure 2. The Comparison between experiment data and pressure drop theory of pure water. 


\subsection{Thermo-pyhsical properties of nanofluid.}

Fig. 3 shows the measurement results of the density of the $\mathrm{Al}_{2} \mathrm{O}_{3}$-water nanofluid under different temperatures. The increase in nanoparticles enhanced the density of the nanofluid, whereas temperature rise reduced it. The influence of volume concentrations on density change appeared to be approximately linear. The pure water density at $30^{\circ} \mathrm{C}$ was almost the same as the nanofluid density at $0.5 \%$ volume concentration at $40^{\circ} \mathrm{C}$, approximately $996 \mathrm{~kg} / \mathrm{m}^{3}$. The results agree with available literature data [22].

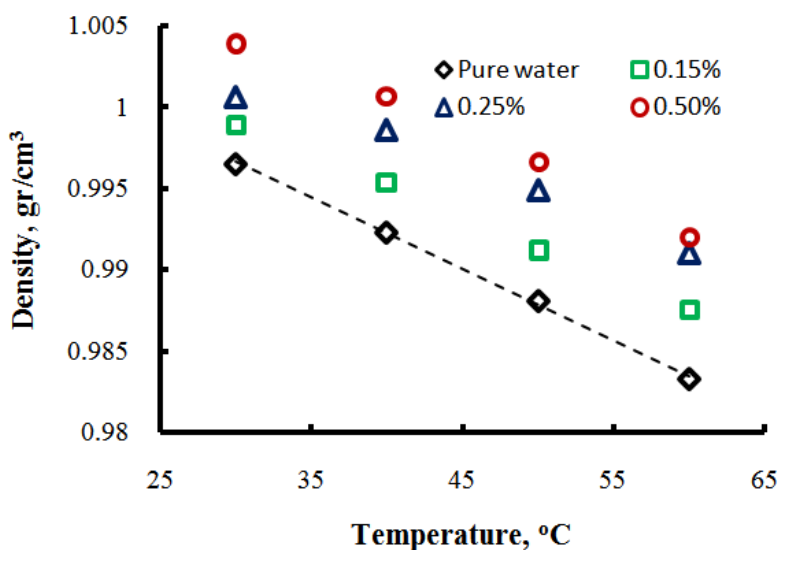

Figure 3. Experiment results for density measurements.

Fig. 4 shows the result of the effect of volume concentrations of $\mathrm{Al}_{2} \mathrm{O}_{3}$-water nanofluid on the changes in viscosity under different temperatures. Temperature rise reduced the viscosity of the nanofluids but increased particle volume concentrations increased nanofluid viscosity. For example, nanofluid viscosity at $30^{\circ} \mathrm{C}$ for $0.15 \%$ particle volume concentration was almost the same as nanofluid viscosity at $40^{\circ} \mathrm{C}$ for $0.5 \%$ particle volume concentration, i.e. $0.87 \mathrm{mPas}$.

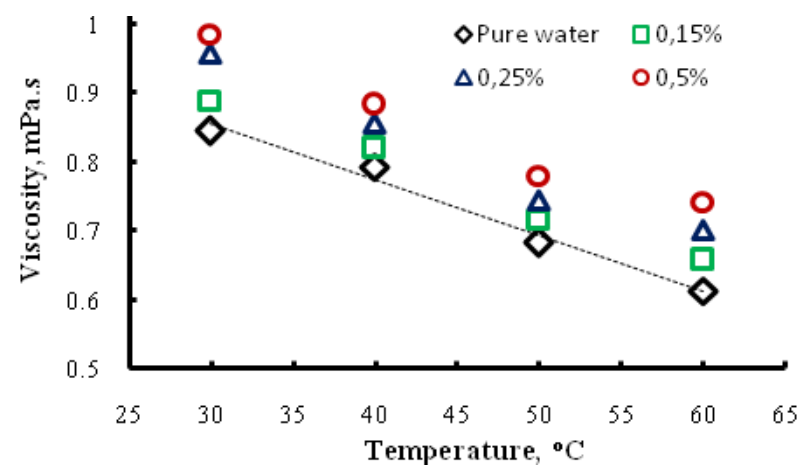

Figure 4. Experiment results for viscosity measurements.

\subsection{Pressure drop and friction factor for the nanofluid under the cooling process.}

Fig. 5 shows the results of effect of volume concentrations of $\mathrm{Al}_{2} \mathrm{O}_{3}$-water nanofluid on the pressure drop and pure water at differing Reynold numbers under the cooling processes. The addition of nanoparticles to the base fluid increased the pressure drop and the value of pressure drop increased with the rise of nanoparticle volume concentrations, and the pressure drops were high at higher volume concentrations. For example, at
Reynold number of 1000 , the pressure drop of alumina nanofluid in $0.5 \%$ volume concentrations was about 750 $\mathrm{Pa}$ and 2.5 times higher than that of pure water, however, it was not significant for nanofluids of $0.15 \%$ volume concentrations. In the cooling process $\left(\mathrm{q}_{\mathrm{w}}<0\right)$ temperature gradient along the radius becomes negative, the temperature effect induces an increasing nanoparticle volume concentration near the tube wall, so nanofluid viscosity increases, but for the lower nanoparticles volume concentration, i.e $0.15 \%$, this effect is not significant.

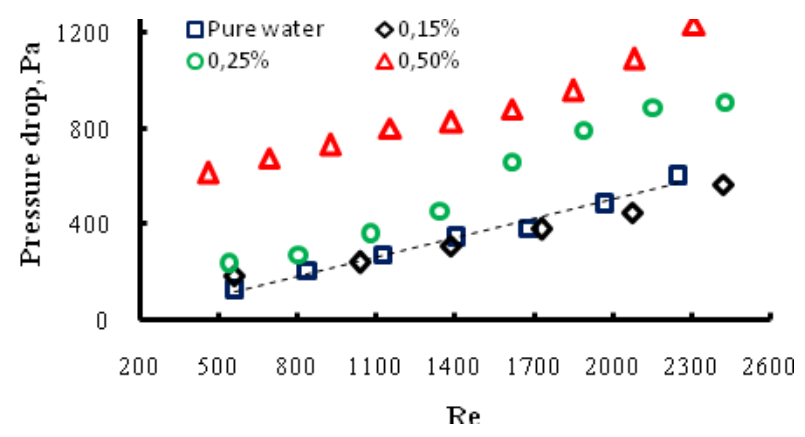

Figure. 5 Experiment pressure drop data for the nanofluid and pure water under the cooling process.

Fig. 6 shows the measured effect of volume concentrations of $\mathrm{Al}_{2} \mathrm{O}_{3}$-water nanofluid on the friction factor at different Reynold numbers calculated by inserting nanofluid thermo-physical properties in Equation (2) under the cooling process. As can be seen, the friction factor of the nanofluids increased with the increasing nanoparticle volume concentrations. For example, at nanoparticle volume concentration of $0.5 \%$, the friction factor was significantly higher than at volume concentrations of $0.15 \%$ and $0.25 \%$. This means that using the $\mathrm{Al}_{2} \mathrm{O}_{3}$-water nanofluid at higher particle volume concentrations may create a penalty in pressure drop. The other reason, being the effect of the distribution of $\mathrm{Al}_{2} \mathrm{O}_{3}$-water nanofluid temperature on radial direction, the temperature of the nanofluids at tube walls for the cooling process was lower than the temperature of nanofluids at the tube axis, this induces higher nanofluid viscosity, since the viscosity of $\mathrm{Al}_{2} \mathrm{O}_{3}$ water nanofluid is dependent on fluid temperature.

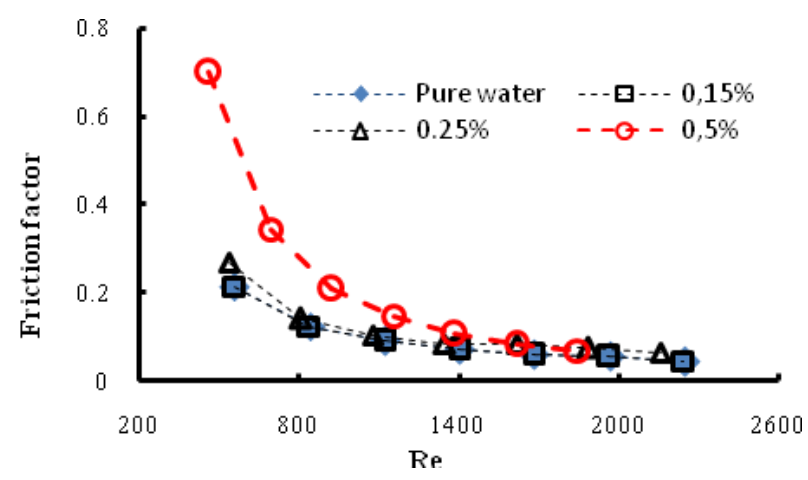

Figure 6. Experiment nanofluid friction factor data under the cooling process.

As can be seen in Fig 6, the friction factor correlation for the pure water in Equation (3) had good agreement at low volume concentrations, i.e. $0.15 \%$ and $0.25 \%$ of nanofluid, but at higher volume concentrations, i.e. $0.5 \%$ the traditional single phase 
correlation Equation (3) failed to predict the pressure drop of the nanofluid. Experiment data obtained for high volume concentrations in this investigation fitted the correlation given in Equation (7).

$$
f=\mathrm{CRe}^{\mathrm{m}} \varphi^{n}
$$

Where, $\mathrm{C}, \mathrm{n}$ and $\mathrm{m}$ are constantly and obtained from experiment investigation.

Using fitting curve and least-square method of the experimental data in the above correlation, friction factor at a high volume concentration, i.e $0.5 \%$ under the cooling process given in equation (8).

$$
f_{n f}=2.27 \mathrm{Re}^{-1.69} \varphi^{-1.75}
$$

Fig. 7 shows the comparison between the new correlation Equation (8) and experimental data friction factor of $\mathrm{Al}_{2} \mathrm{O}_{3}$-water nanofluids. The maximum deviations between the experiment and the new predicted correlation were reduced to within the range of $-13.64 \%$ to $9.98 \%$.

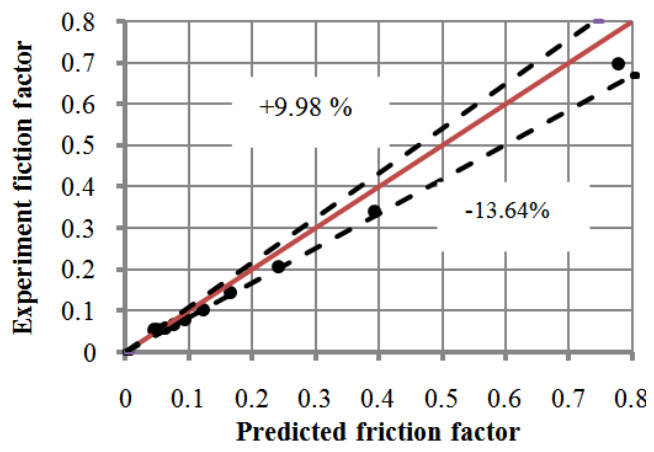

Figure 7. The Comparison of experiment and predicted friction factor of nanofluids.

\subsection{Pressure drop of nanofluid under the heating process.}

Fig. 8 shows the measured effect of volume concentrations of $\mathrm{Al}_{2} \mathrm{O}_{3}$-water nanofluid on the pressure drop and that of pure water at differing Reynold numbers under the heating processes. The pressure drop from the heating process for all nanofluid volume concentrations was almost the same as for pure water. The heating caueses the viscosity near the wall region to be lower than the viscosity at the tube axis, the particle moved to the axis of tube due to thermophoresis effects. The friction factor was lower than that of pure water and the traditional single phase correlation can be used to predict pressure drop of nanofluids in this study.

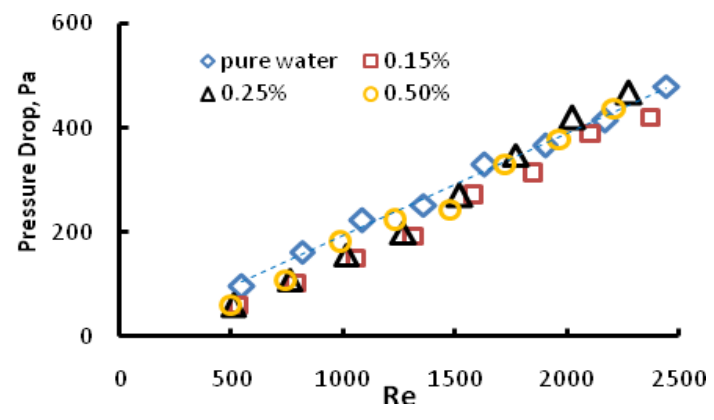

Figure. 8 Experiment pressure drop data of nanofluid and pure water under the heating process.

\section{CONCLUSION}

In this paper, the pressure drop of $\mathrm{Al}_{2} \mathrm{O}_{3}$-water nanofluids flowing through a circular pipe in both the cooling and heating processes in a fully developed region was investigated experimentally. The physical properties of $\mathrm{Al}_{2} \mathrm{O}_{3}$-water nanofluids, i.e. the viscosity and density, were measured over a temperature range of $30-60^{\circ} \mathrm{C}$ in nanoparticle volume concentrations of $0.15 \%, 0.25 \%$ and $0.5 \%$ respectively. For the traditional single phase correlation in Equation (3) there was good agreement for nanofluids at low volume concentrations i.e. $0.15 \%$ and $0.25 \%$ under the cooling process. But, at higher volume concentrations i.e. $0.5 \%$, the traditional single phase correlation failed to predict nanofluid pressure drop. Based on the experiment data, new correlations are proposed for calculating nanofluid friction factors at high volume concentrations as a function of the Reynold number for the cooling process. The maximum deviations between the experiment pressure drop result and new correlations were reduced to within $-16 \%$ to $17.2 \%$, respectively. But in the heating process, there was good agreement for the traditional single phase correlation in predicting pressure drop of nanofluids in this study. Thermophoresis effects and temperature dependence is also an important parameter in the pressure drop of nanofluids. When the application of nanofluid is considered, two important issues are viscosity and density. It should be noted that increasing the viscosity by the use of nanofluids has important drawback due to the associated necessity of increasing pumping power, but higher temperatures reduce viscosity and decrease the pumping power needs.

\section{ACKNOWLEDGMENT}

The authors would like to thanks the Indonesian Higher Education (DIKTI) for providing financial support for this study.

\section{REFERENCES}

[1] Maxwell, J.C.: A Treatise on Electricity and Magnetism, $3^{\text {rd }}$ ed., Oxford University Press, London, 1892.

[2] Choi, S.U.S.: Enhancing thermal conductivity of fluids with nanoparticles, In: D.A. Siginer and H.P. Wang (Eds), Developments and Applications of Non-Newtonian Flows, ASME FED, 231/MD, Vol. 66, pp. 99-105, 1995.

[3] Das, S.K., Putra, N., Thiesen, P. and Roetzel, W.: Temperature dependence of thermal conductivity enhancement for nanofluid, ASME J. Heat Transfer, Vol. 125, pp. 567-574, 2003.

[4] Hwang, Y., Lee, J. K., Jung, C.H., Cheong, S.I., Lee, C.G., Ku, B.C. and Jang, S.P.: Stability and thermal conductivity characteristics of nanofluids, Thermochim. Acta, Vol. 455, pp. 70-74, 2007.

[5] Murshed, S.M.S., Leong, K.C. and Yang, $\mathrm{C}$.:Enhanced thermal conductivity of $\mathrm{TiO}_{2}$-water based nanofluids, Int. J of Thermal Science, Vol. 44, pp.567-574, 2005. 
[6] Yu, W. and Choi, S.U.S.: The Role of interfacial layers in the enhanced thermal conductivity of nanofluids: A Renovated Maxwell Model, J. Nanopart. Res, Vol. 5, pp. 167-171, 2003.

[7] $\mathrm{Yu}, \mathrm{W}$. and Choi, S.U.S.: The Role of interfacial layers in the enhanced thermal conductivity of nanofluids: A Renovated Hamilton-Crosser Model, J. of Nanoparticle Research, Vol. 6, pp. 167-171, 2004.

[8] Xue, Q. Z.: Model for effective thermal conductivity of nanofluids, Phys. Lett. A, Vol. 307, pp. 313-317, 2004.

[9] Koo, J. and Kleinstreuer, C.: A new thermal conductivity model for nanofluids, J. Nanopart. Res, Vol. 6, pp. 577- 588, 2004.

[10] Prasher, R., Bhattacharya, P. and Phelan, P.E.: Brownion motion-based convective-conductive model for the effective thermal conductivity of nanofluid, ASME - J. Heat Transfer, Vol.128, pp. 588-595, 2006.

[11]Jang, S.P. and Choi, S.U.S.: Role of Brownion motion in the enhanced thermal conductivity of nanofluid, Appl. Phys. Lett, Vol. 84, pp. 43164318, 2004.

[12] Jang, S.P. and Choi, S.U.S.: Effects of parameter on nanofluid thermal conductivity, Appl. Phys. Lett, Vol. 129, pp. 617-623, 2007.

[13] Wen, D. and Ding, Y.: Experimental investigation into convective heat transfer of nanofluid at the entrance region under laminar flow conditions, Int. J. Heat Mass Transfer, Vol. 47, pp. 5181-5188, 2004.

[14]Heris, S.Z., Etemad, S. and Esfahany, M.N.: Experimental investigation of oxide nanofluids laminar flow convective heat transfer, In. Comm. in Heat Mass Transfer, Vol. 33, No. 4, pp. 529-535, 2006.

[15] Yang, Y., Zhang, Z.G., Grulke, E.A., Anderson W.B. and $\mathrm{Wu}$. G.: Heat transfer properties of nanoparticle in-fluid dispersion (nanofluids) in laminar flow, Int. J. Heat Mass Transfer, Vol. 48, pp. 1107-1116, 2005.

[16] Duangthongsuk, W and Wongwises, S.: Heat transfer enhancement and pressure drop characteristics of $\mathrm{TiO}_{2}$-water nanofluids in doubletube counter flow heat exchanger, Int. J. Heat Mass Transfer, Vol. 52, pp. 2059-2067, 2009.

[17] Vajjha,R.S., Das, D.K. and Kulkarni, D.P.: Development of new correlations for convective heat transfer and friction factor in turbulent regime for nanofluid, Int. J. Heat Mass Transfer, Vol. 53, pp. 4067- 4618, 2010.

[18] Suresh, S., Selvakumar, P., Chandrasekar, M. and Raman, V.S.: Experimental studies on heat transfer and friction factor characteristics of $\mathrm{Al}_{2} \mathrm{O}_{3}$ /water nanofluid under turbulent flow with spiraled rod inserts, Chem. Eng. Process, Vol. 53, pp. $24-30$, 2012.
[19] Heyhat, M.M., Kowsary, F., Rashidi, A.M., Momenpour, M.H. and Amrollahi, A.: Experimental investigation of laminar convective heat transfer and pressure drop of water-based $\mathrm{Al}_{2} \mathrm{O}_{3}$ nanofluids in fully developed flow regime, Exp. Therm Fluid Sci, Vol. 44, pp. 483-489, 2013.

[20] Teng, T.P., Hung, Y.H., Jwo, C.C, Chen, C.C. and Jeng, L.Y.: Pressure drop of $\mathrm{TiO}_{2}$ nanofluid in circular pipes, Particuology, Vol. 9, pp. 486-491, 2011.

[21]Lee, D., Kim, J.W. and Kim, B.G.: A new parameter to control heat transport in nanofluids: surface charge state of the particle in suspension, J. Phys. Chem, Vol. 8, B 110: 4323-8, 2006.

[22] Incropera, F.P., Dewitt, D.P., Bergman,T.L. and Lavine, A.S.: Fundamentals of Heat and Mass Transfer, 7th ed., John Wiley \& Sons, New York, 2011.

[23] Doebelin, E.: Measurement Systems Application and Design, 5th. ed., Mc Graw-Hill, 2004.

\section{NOMENCLATURE}

\begin{tabular}{|c|c|}
\hline $\operatorname{Re}$ & Reynold number \\
\hline A & Cross section area, $\left[\mathrm{m}^{2}\right]$ \\
\hline d & Diameter of tube, $[\mathrm{m}]$ \\
\hline $\mathrm{f}$ & Friction factor, $[-]$ \\
\hline $\mathrm{k}$ & Thermal conductivity, $\left[\mathrm{W} \mathrm{m} \mathrm{m}^{-1} \mathrm{~K}^{-1}\right.$ ] \\
\hline $\mathrm{L}$ & Length of the test tube, $[\mathrm{m}]$ \\
\hline$\Delta \mathrm{P}$ & Pressure drop, $[\mathrm{Pa}]$ \\
\hline $\mathrm{q}_{\mathrm{w}}$ & Heat flux, $\left[\mathrm{W} \mathrm{m}^{-2}\right]$ \\
\hline $\mathrm{r}$ & Radius $[\mathrm{m}]$ \\
\hline $\mathrm{T}$ & Operating temperature, $[\mathrm{K}]$ \\
\hline $\bar{U}$ & Average velocity, $\left[\mathrm{m} \mathrm{s}^{-1}\right]$ \\
\hline
\end{tabular}

\section{GREEK SYMBOLS}

$\begin{array}{ll}\mu & \text { Dynamic viscosity }[\mathrm{Pa} \mathrm{s}] \\ v & \text { Kinematic viscosity }\left[\mathrm{m}^{2} \mathrm{~s}^{-1}\right] \\ \phi & \text { Volume concentrations }[\%] \\ \rho & \text { Density }\left[\mathrm{kg} \mathrm{m}^{-3}\right]\end{array}$

\section{SUBSCRIPS \\ $b \quad$ Base fluid \\ $o \quad$ Outlet \\ $f \quad$ Fluid \\ $i \quad$ Inlet \\ nf Nanofluid \\ $o \quad$ Outlet \\ $p \quad$ Particle \\ w Wall}


У раду се разматра пад притиска у нанофлуиду састављеног од воде и $\mathrm{Al}_{2} \mathrm{O}_{3}$ у условима режима ламинарног струјања у кружним цевима на различитим температурама и при различитим запреминским концентрацијама $\mathrm{Al}_{2} \mathrm{O}_{3}$ код процеса хлађења и грејања. Применом класичне корелације за израчунавање пада притиска не може прецизно да се процени пад притиска код ламинарног струјања у процесу хлађења, али је то могуће код процеса грејања. Овим истраживањем су из тог разлога развијене нове корелације за израчунавање фактора трења код ламинарног струјања у процесу хлађења при већим запреминским концентрацијама $(0,5 \%)$. Утврђено је да нанофлуид састављен од воде и $\mathrm{Al}_{2} \mathrm{O}_{3}$ наночестица поспешује пад притиска, а и да пораст температуре такође смањује пад притиска. Максимална одступања између нове израчунате корелације и експерименталних резултата редукована су у распону од $-13,64 \%$ до $+9,98 \%$. 